\title{
Ten Year Results of a Fibromyalgia Out-Patient Clinic: Is There a Happy Ending?
}

\author{
Bir Fibromiyalji İzlem Polikliniğinin 10 Yıllık Sonuçları: Mutlu Son Var mı?
}

\author{
Burcu YANIK, ${ }^{1}$ Derya GÖKMEN, ${ }^{2}$ Ümit SARP, ${ }^{3}$ Yeşim KURTAİ̧ AYTÜR, ${ }^{3}$ Süreyya ERGİN ${ }^{3}$ \\ ${ }^{1}$ Department of Physical Medicine and Rehabilitation, Medical Faculty of Fatih University, Ankara, Turkey; \\ Departments of ${ }^{2}$ Biostatistics, ${ }^{3}$ Physical Medicine and Rehabilitation, Medical Faculty of Ankara University, Ankara, Turkey
}

\begin{abstract}
Objectives: In this retrospective cohort, we determined the clinical characteristics, treatment options and outcomes of fibromyalgia syndrome (FMS) patients and reported the results of the 10 years of experience of our Fibromyalgia Follow-up Outpatient Clinic (FOC).

Patients and methods: Of the 308 patients (247 females, 61 males) who were referred to the FOC with suspicion of FMS, 252 were diagnosed with FMS. The demographic data of all patients were recorded. The patient forms of the FOC were used to question whether the patients had widespread body pain, fatigue, sleep disorders, morning stiffness, paresthesia, Raynaud's phenomenon, dry eye, dry mouth, irritable bowel syndrome, headaches, decreased libido, symptoms of female urethral syndrome, or subjective swelling. The level of pain intensity, presence of a sleep disorder, number of tender points, total myalgic score, the fibromyalgia impact questionnaire (FIQ), the health assessment questionnaire (HAQ) and Beck depression inventory (BDI) were also recorded after each visit done in three or six month intervals. All the recorded data were analyzed taking into consideration missing data.
\end{abstract}

Results: The disease duration, number of tender points, total myalgic score $(p<0.001), H A Q$-total, headache, paresthesia, sleep disorders, morning stiffness, reduction in libido and irritable bowel syndrome $(p<0.05)$ showed a statistically significant difference between FMS (+) and FMS (-) patients. The clinical parameters of the number of days in a week the patient had difficulty falling asleep (sleep-1), total myalgic score, FIQ-total and HAQ-total scores in FMS (+) patients showed significant changes over time. The FIQ-total and pain improved significantly in patients who had been administered selective serotonin re-uptake inhibitor drugs $(p<0.05)$. The FMS $(+)$ patients who were treated with amitriptyline showed significant improvement in sleep-1: however, no significant difference was detected in clinical parameters of the patients taking sertraline.

Conclusion: Since FMS is a musculoskeletal disorder with a wide variety of clinical signs and symptoms, it is essential to evaluate every patient individually according to predominant clinical features in order to apply the best treatment. Dividing these patients into subgroups may be useful.

Key words: Fibromyalgia syndrome; medication; outcome; retrospective study; subgroup.
Amaç: Bu geriye dönük özdeş grup çalışmasında, fibromiyalji sendromlu (FMS) hastaların klinik özellikleri, tedavi seçenekleri ve sonuçları belirlendi ve Fibromiyalji İzlem Polikliniğimizde (FiP) edinilen 10 yıllık deneyimlerin sonuçları sunuldu.

Hastalar ve yöntemler: Fibromiyalji sendromu şüphesi ile FiP'ye sevk edilen 308 hastanın (247 kadın, 61 erkek) 252'sine FMS tanısı konuldu. Tüm hastaların demografik verileri kaydedildi. Fibromiyalji izlem polikliniği'nin hasta formları kullanılarak hastalarda yaygın vücut ağrısı, yorgunluk, uyku bozukluğu, sabah tutukluğu, parestezi, Raynaud fenomeni, göz kuruluğu, ağız kuruluğu, iritabl bağırsak sendromu, baş ağrısı, libido azalması, kadın üretral sendromu semptomları veya subjektif şişlik mevcut olup olmadığı sorgulandı. Üç veya altı aylık aralıklarla yapılan her görüşmenin sonunda ağrı şiddeti, uyku bozukluğu, hassas nokta sayısı, total miyaljik skor, fibromiyalji etki anketi (FEA), sağlık değerlendirme anketi (SDA) ve Beck depresyon envanteri (BDE) de kaydedildi. Kaydedilen tüm veriler eksik verileri dikkate alınarak analiz edildi.

Bulgular: FMS (+) ve FMS (-) hastalar arasında hastalık süresi, hassas nokta sayısı, total miyaljik skor $(p<0.001)$, BDE, baş ağrısı, parestezi, uyku bozuklukları, sabah tutukluğu, libido azalması ve iritabl bağırsak sendromu $(p<0.05)$ açılarından istatistiksel olarak anlamlı farklıık saptandı. FMS (+) hastalarda, bir hafta boyunca uykuya dalma güçlüğü çekilen gün sayısı (uyku-1), total miyaljik skor, toplam FEA skoru ve toplam SDA skoru şeklindeki klinik parametreler açısından zaman içerisinde anlamlı değişiklikler görüldü. Giriş ve son kontrol arasında, selektif serotonin geri alım inhibitörü ilaç alan hastalarda total FEA skoru ve ağrıda anlamlı iyileşme görüldü $(p<0.05)$. Amitriptilin tedavisi uygulanan FMS $(+)$ hastalarda uyku-1'de anlamlı iyileşme görüldü, bununla birlikte sertralin ile klinik parametrelerde anlamlı farklılık saptanmadı.

Sonuç: Fibromiyalji sendromu çok çeşitli klinik belirti ve semptomlarla seyreden bir kas-iskelet sistemi hastalığı oldundan, en uygun tedavinin uygulanabilmesi için her hastanın ağırlıklı klinik özelliğine göre değerlendirilmesi şarttır. Bu hastaları alt gruplara ayırmak yararlı olabilir.

Anahtar sözcükler: Fibromiyalji sendromu; ilaç tedavisi; sondurum; retrospektif çalışma; alt grup.

Received: September 9, 2009 Accepted: January 18, 2010

Correspondence: Burcu Yanık, M.D. Fatih Üniversitesi Tıp Fakültesi Fiziksel Tıp ve Rehabilitasyon Anabilim Dalı, 06510 Emek, Ankara, Turkey.

Tel: +90 312 - 4957066 e-mail: burcucorek@hotmail.com

Presented at the $5^{\text {th }}$ ISPRM World Congress, June 13-17, 2009, Istanbul, Turkey.

(C2011 Turkish League Against Rheumatism. All rights reserved. 
Fibromyalgia syndrome (FMS) is characterized by widespread musculoskeletal pain and accompanying symptoms such as fatigue and disturbed sleep. Although a frequent disorder, it is usually considered as psychosomatic and cannot be diagnosed accurately by many clinicians. It is a common cause of decreased quality of life and disability. ${ }^{[1]}$ The American College of Rheumatology (ACR) classification criteria for FMS includes a history of widespread pain in addition to axial skeletal pain of at least three months duration and pain on palpation in at least 11 of 18 paired tender points. [2] The criteria are approximately $88 \%$ sensitive and $81 \%$ specific for the diagnosis of FMS. ${ }^{[3]}$ Fibromyalgia syndrome is often considered as a disorder of women between 20 to 50 years of age, but it is diagnosed in men and children as well. The etiopathogenesis is still obscure although there are many hypotheses including neurohumoral dysfunction. ${ }^{[4]}$ Moreover, because FMS is classified in the group of central sensitivity syndromes, ${ }^{[5]}$ there is debate on whether it should be accepted as a neuropathic pain syndrome or not. ${ }^{[6]}$

There are many difficulties in the diagnosis and treatment of FMS because there are varying nonspecific symptoms. Patients must be carefully assessed regarding their predominant symptoms so that treatment can be planned accordingly. Some authors recommend evaluating fibromyalgia patients according to subgroups. Giesecke et al, ${ }^{[7]}$ defined three groups of fibromyalgia patients on the basis of patterns of pressure-pain sensitivity, mood and cognition. Turk et $\mathrm{al}^{\left[{ }^{[8]}\right.}$ considered FMS as a heterogeneous disorder and also classified patients into three groups based on psychosocial and behavioral characteristics. On the other hand, Müller et al, ${ }^{[9]}$ recommended dividing patients into four groups according to the existence of pain, depression secondary to pain, depression with concomitant FMS, and somatoform disorder. The authors suggested treatment with 5-HT3 receptorblocking agents in the subgroup with high pain sensitivity, antidepressant therapy for the subgroup characterized by depression, and psychotherapy in the group with somatoform pain disorder. This approach relies on the idea that each classified group may benefit from discrepant therapy modalities because of the differences in their predominant symptoms. All these efforts reveal the lack of standard algorithms for both assessment and treatment of patients with FMS. This is partly because of the nature of the disease itself.

These difficulties led us to set up a specialized fibromyalgia outpatient clinic (FOC) in our department 10 years ago. The primary aim was to discriminate between patients with FMS and other patients with chronic pain, and to treat them accordingly. In the FOC, all patients referred from other outpatient and inpatient clinics with a suspicion of FMS are examined and investigated in detail. Later on, patients diagnosed with FMS are followed up and evaluated in three or six month intervals. These patients are assessed individually according to the predominant clinical feature(s) in order to plan the most appropriate treatment. When the predominant symptom is pain, patients are first given analgesic drugs or physical therapy. Patients with predominant symptoms of sleep disorder or anxiety need to be treated with drugs such as selective serotonin receptor inhibitors (SSRI) or tricyclic antidepressants (TCA). Patients with a disability may have a better outcome with aerobic and/or $f$ lexibility exercises.

In this retrospective study, the aim is to determine the clinical characteristics, treatment options and outcome of fibromyalgia patients followed up in a specialized fibromyalgia outpatient clinic and to report the results of ten years' experience.

\section{PATIENTS AND METHODS}

\section{Patients}

In this retrospective cohort, the records of the patients who were registered to the FOC between 1999 and 2008 were reviewed. Since it would be too complicated to analyze all the recorded visits and since not all patients had the same number of visits, it was decided to present the records of the baseline, first visit (one month after baseline), and last visit available. The inclusion criteria were the fulfillment of the ACR 1990 classification criteria for FMS, or having concomitant symptoms like widespread musculoskeletal pain and/or sleep disorders for patients who did not have more than 11 tender points out of 18. Diagnosis was made mainly according to the medical doctors' opinion, but classification criteria were also used as a secondary tool. The patients who were not diagnosed with FMS after detailed examination and those whose primary diagnosis by a psychiatrist were major depression or major anxiety disorders were excluded from analysis. The age, gender, and occupational and marital status of patients were recorded in addition to their complaints, duration of disease, comorbid conditions, and drugs used. The FOC patient forms contained information on whether or not the patients had widespread body pain, fatigue, sleep disorder, morning stiffness, paresthesia, Raynaud's phenomenon, dry eye, dry mouth, irritable bowel syndrome, headache, decreased 
libido, symptoms of female urethral syndrome, or subjective swelling. Detailed physical and laboratory examinations including blood count, liver and kidney function, erythrocyte sedimentation rate, C-reactive protein, rheumatoid factor, anti-nuclear antibody, thyroid stimulating hormone and free thyroid-4 hormone levels for thyroid function were undertaken. A radiological investigation was done as needed in the first visit.

Patients suspected to have FMS had been referred to the FOC of the Physical Medicine and Rehabilitation Department from the inpatient and outpatient clinics of our university hospital. After a thorough examination and some necessary laboratory tests, the patients who were diagnosed with FMS were registered and followed up in three or six month intervals. The patients were reexamined one month after the initiation of new treatment in order to assess compliance of the patient with the new drug and record any adverse side effects. The patients were informed about the nature of their disease and were recommended to continue their regular follow-up visits to maintain an active lifestyle and to avoid physiological stress. The treatment options including pharmacologic and non-pharmacologic (physical therapy, various exercise modalities, etc) therapies offered were always discussed with the patient in order to make a shared decision. Sometimes more than one treatment modality was applied at a time, and sometimes a step-up approach was administered.

\section{Pain intensity}

Pain intensity was assessed by visual analog scale (VAS) and Likert scale. The patients were asked to rate their pain intensity on a $10 \mathrm{~cm}$ horizontal linear line on the VAS. The patients graded their pain on a 5-point (0-4) Likert scale as 0 (none), 1 (mild), 2 (moderate), 3 (severe), and 4 (intolerable).

\section{Sleep disorder}

Sleep was assessed with three questions. The first question (sleep-1) asked about the number of days in a week the patient had difficulty falling asleep. The second (sleep-2) assessed the frequency of waking-up during the night with a 3-point (0-2) Likert scale from 0 ("I do not wake up at nights"), to 1 ("I wake up at some nights") and 2 ("I wake up every night"). The third question (sleep-3) asked about the quality of sleep ("the fatigue felt in the morning"). The options ranged from 0 ("I wake up fresh every morning") to 1 ("I wake up fresh sometimes") and 2 ("I never wake up fresh in the mornings").

\section{Number of the tender points and total myalgic score}

A moderate and consistent degree of pressure was used in digital palpation of the 18 anatomic tender points recommended by the ACR 1990 criteria and four symmetrical control points. The amount of force applied was approximately $4.0 \mathrm{~kg}$ as recommended.

\section{The fibromyalgia impact questionnaire (FIQ) ${ }^{[10]}$}

The FIQ was developed in the late 1980s by Burckhardt et al. ${ }^{[10]}$ in an attempt to capture the total spectrum of problems related to FMS and the responses to therapy. It was designed to measure the components of health status that are believed to be most affected by FMS. The FIQ is composed of 10 items. The first item contains 11 questions related to physical functionality with each question rated on a 4-point Likert-type scale. Items 2 and 3 ask the patient to mark the number of days they felt well and the number of days they were unable to work (including housework) because of fibromyalgia symptoms. Items 4 through 10 are horizontal linear scales marked in 10 increments on which the patient rates work difficulty, pain, fatigue, morning tiredness, stiffness, anxiety and depression. The FIQ is a selfadministered instrument that takes approximately five minutes to complete. The directions are simple, and the scoring is self- explanatory. The instrument was shown to be valid in our native language, ${ }^{[11]}$ and the validated version began to be used before the results were published.

\section{The health assessment questionnaire $(H A Q)^{[12]}$}

The HAQ is one of the first self-reporting functional status (disability) measures and has become the dominant assessment instrument for many diseases, including arthritis. It was developed as a comprehensive instrument to measure outcome in patients with a wide variety of rheumatic diseases, including rheumatoid arthritis, osteoarthritis, juvenile rheumatoid arthritis, lupus, scleroderma, ankylosing spondylitis, FMS and psoriatic arthritis. It focuses on self-reported, patientoriented outcome results. The eight categories used in the HAQ are dressing and grooming, arising, eating, walking, hygiene, reach, grip and common daily activities. There are four possible responses for the questions- 0 (without any difficulty), 1 (with some difficulty), 2 (with much difficulty) and 3 (unable to do). A high total value indicates severe effects on daily activities. The HAQ was shown to be valid in our native language. ${ }^{[13]}$ When the clinic was first established, it was uncertain whether the HAQ and FIQ would equally assess the sensitivity to change in patients, so we 
preferred to use the HAQ scale (first the unvalidated translation, and then the validated version) instead of a disease-specific disability measurement.

\section{Beck depression inventory $(B D I)^{[14]}$}

Each of the 21 items on the BDI consists of four statements representing increasing degrees of severity with scores ranging from 0 to 3 . Total scores on the BDI can range from zero (no depression) to a maximum score of 63 (severe state of depression). A BDI score of 10 or greater is considered to indicate the possibility of at least mild depression. The BDI was also translated into our language and a validation study was done prior to the start of the study. ${ }^{[15]}$

Pain intensity (VAS and Likert), sleep disturbance (sleep-1, 2, 3), number of tender points, total myalgic score, the FIQ, the HAQ and the BDI were applied to patients at recruitment and at every visit thereafter. In this study, only the data from the recruitment, intermediate visit and the last visit were evaluated. They are referred to as baseline, first visit and last visit respectively throughout the text. Treatment modalities were also analyzed for each visit.

\section{Statistical analysis}

Data were analyzed using SPSS for Windows version 11.5, (SPSS Inc., Chicago, Illinois, USA). The demographic and clinical characteristics of the patients were compared by Student t-test and MannWhitney U-test for continuous or ordinal data, and Chi-Square test for nominal data. Descriptive statistics were given as the median (minimum-maximum) and the number and percentage (\%) of the patients. The Spearman correlation coefficient was calculated for the correlations of the patient characteristics and the parameters at follow-up. The non-parametric Friedman test was used for the changes between the three visits. The Friedman post-hoc test was used to

Table 1. Demographic and clinical characteristics of the patients with fibromyalgia syndrome and without fibromyalgia syndrome

\begin{tabular}{|c|c|c|c|c|c|}
\hline \multirow{3}{*}{$\begin{array}{l}\text { Demographic features } \\
\text { Age (year) }\end{array}$} & \multirow{2}{*}{\multicolumn{2}{|c|}{$\begin{array}{c}\begin{array}{c}\text { Fibromyalgia }(+) \\
(\mathrm{n}=252)\end{array} \\
\text { Median (min.-max.) }\end{array}$}} & \multirow{2}{*}{\multicolumn{2}{|c|}{$\begin{array}{l}\begin{array}{c}\text { Fibromyalgia }(-) \\
(\mathrm{n}=56)\end{array} \\
\text { Median (min.-max.) }\end{array}$}} & \multirow{3}{*}{$\begin{array}{c}p \\
0.742\end{array}$} \\
\hline & & & & & \\
\hline & \multirow{3}{*}{$\begin{array}{l}43 \\
48\end{array}$} & \multirow{2}{*}{$\begin{array}{l}(18-74) \\
(1-360)\end{array}$} & \multirow{2}{*}{$\begin{array}{l}44 \\
24\end{array}$} & \multirow{3}{*}{$\begin{array}{l}(17-64) \\
(1-132)\end{array}$} & \\
\hline Symptom duration (month) & & & & & \multirow[t]{2}{*}{0.000} \\
\hline \multicolumn{3}{|l|}{ Pain intensity } & & & \\
\hline Visual analog scale (mm) & 67 & $(0-100)$ & 57 & $(0-100)$ & 0.088 \\
\hline Likert $(0-4)$ & 2 & $(0-4)$ & 2 & $(0-4)$ & 0.240 \\
\hline Sleep-1 (day) & 3 & $(0-7)$ & 3 & $(0-7)$ & 0.272 \\
\hline Sleep-2 (0-2) & 1 & $(0-3)$ & 1 & $(0-2)$ & 0.143 \\
\hline Sleep-3 (0-2) & 2 & $(0-2)$ & 2 & $(0-2)$ & 0.410 \\
\hline Number of tender points & 16 & $(2-18)$ & 9.5 & $(0-18)$ & 0.000 \\
\hline Total myalgic score & 23 & $(2-44)$ & 12.5 & $(0-46)$ & 0.000 \\
\hline Fibromyalgia impact questionnaire total & \multicolumn{2}{|c|}{$5.65(0.74-9.40)$} & 5.47 & $(1.83-8.37)$ & 0.124 \\
\hline Health assessment questionnaire total & \multirow{2}{*}{\multicolumn{2}{|c|}{$\begin{array}{cc}0.42 & (0-1.68) \\
13 & (0-41)\end{array}$}} & \multirow{2}{*}{\multicolumn{2}{|c|}{$\begin{array}{c}(0-1.32) \\
(0-30)\end{array}$}} & 0.046 \\
\hline Beck depression inventory total & & & & & 0.830 \\
\hline Clinical characteristics & $\mathrm{n}$ & $\%$ & $\mathrm{n}$ & $\%$ & $p$ \\
\hline Fatigue & 242 & 96 & 52 & 92.9 & 0.303 \\
\hline Widespread pain & 230 & 91.3 & 47 & 83.9 & 0.099 \\
\hline Headache & 220 & 87.3 & 41 & 73.2 & 0.006 \\
\hline Paresthesia & 212 & 84.1 & 37 & 66.1 & 0.004 \\
\hline Sleep disorder & 203 & 80.6 & 36 & 64.3 & 0.008 \\
\hline Morning stiffness & 184 & 73 & 32 & 57.1 & 0.019 \\
\hline Subjective swelling & 166 & 65.9 & 36 & 64.3 & 0.893 \\
\hline Reduction in libido & 151 & 59.9 & 21 & 41.2 & 0.003 \\
\hline Dry mouth & 146 & 57.9 & 27 & 49.1 & 0.228 \\
\hline Irritable bowel & 127 & 50.4 & 16 & 28.6 & 0.003 \\
\hline Female urethral syndrome & 93 & 36.9 & 18 & 32.1 & 0.937 \\
\hline Dry eye & 92 & 36.5 & 20 & 35.7 & 0.866 \\
\hline Raynaud's phenomenon & 52 & 20.6 & 8 & 14.3 & 0.293 \\
\hline
\end{tabular}


determine the differences between two visits. $\mathrm{P}<0.05$ was considered as statistically significant.

\section{RESULTS}

Of the 308 patients who were referred to the clinic, 252 patients $(81.8 \%)$ were diagnosed with FMS. There were no drop-outs in FMS (+) patients. The demographic and clinical features of the FMS (+) and FMS (-) patients are summarized in table 1 . The disease duration, number of tender points, total myalgic score $(\mathrm{p}<0.001)$,

Table 2. Demographic and clinical characteristics of the patients with fibromyalgia syndrome

\begin{tabular}{|c|c|c|}
\hline Patient characteristics & $\mathrm{n}$ & $\%$ \\
\hline \multicolumn{3}{|l|}{ Marital status } \\
\hline Married & 216 & 85.7 \\
\hline Single & 25 & 9.9 \\
\hline Widowed & 10 & 4 \\
\hline Divorced & 1 & 0.4 \\
\hline \multicolumn{3}{|l|}{ Occupation } \\
\hline Housewife & 184 & 74.2 \\
\hline Employee & 36 & 14.5 \\
\hline Retired & 27 & 9.3 \\
\hline Student & 5 & 2 \\
\hline \multicolumn{3}{|l|}{ Pain intensity (Likert) } \\
\hline None & 3 & 1.2 \\
\hline Mild & 11 & 4.3 \\
\hline Moderate & 119 & 47.2 \\
\hline Severe & 80 & 31.8 \\
\hline Intolerable & 39 & 15.5 \\
\hline \multicolumn{3}{|l|}{ Sleep-2 } \\
\hline None & 33 & 13 \\
\hline Some nights & 97 & 38.5 \\
\hline Every nights & 122 & 48.5 \\
\hline \multicolumn{3}{|l|}{ Sleep-3 } \\
\hline Every morning & 14 & 5.6 \\
\hline Some morning & 88 & 34.9 \\
\hline Neither morning & 150 & 59.5 \\
\hline \multicolumn{3}{|l|}{ Complaint } \\
\hline Generalized pain & 159 & 63 \\
\hline Back pain & 50 & 19.8 \\
\hline Shoulder pain & 37 & 14.6 \\
\hline Neck pain & 30 & 11.9 \\
\hline Low back pain & 18 & 7.1 \\
\hline \multicolumn{3}{|l|}{ Comorbidity } \\
\hline None & 92 & 36.5 \\
\hline Hypertension & 45 & 17.8 \\
\hline Hypothyroidism & 39 & 15.4 \\
\hline Gastritis & 22 & 8.7 \\
\hline Diabetes mellitus & 13 & 5.1 \\
\hline Asthma & 10 & 3.9 \\
\hline Hyperlipidemia & 10 & 3.9 \\
\hline Major depression & 8 & 3.1 \\
\hline Migraine & 8 & 3.1 \\
\hline Behcet's syndrome & 8 & 3.1 \\
\hline Anemia & 7 & 2.7 \\
\hline
\end{tabular}

HAQ-total, headache, paresthesia, sleep disorders, morning stiffness, reduction in libido and irritable bowel syndrome $(\mathrm{p}<0.05)$ showed statistically significant difference between FMS (+) and FMS (-) patients.

Two hundred forty-seven (98\%) of the FMS patients were female. Twenty-nine (11.5\%) of the patients were at the postmenopausal stage. The marital status, occupation, pain intensity, sleep disorders, complaints and comorbidities are summarized in table 2. Lumbar disc herniation (2.3\%), osteoporosis (2.2\%), osteoarthritis (1.1\%), anxiety (0.7\%), and allergic disorders $(0.3 \%)$ were other comorbidities seen in the study but in numbers too small to be statistically significant. The drugs prescribed to the FMS patients at baseline, first and last visit are presented in table 3 . The other drugs prescribed less frequently were mirtazapine, tianeptine, trazodone, chlorpromazine and moclobemide. The dosage of the drugs used was titrated according to the severity of symptoms. Psychiatrists also assessed a considerable percentage of the patients, and some of the drugs were prescribed after consultation with them.

The pain intensity, number of tender points, total myalgic score, FIQ-total, HAQ-total, BDI-total, disease duration and some patient characteristics were found to be significantly correlated $(\mathrm{p}<0.05)$. Age was not correlated with any of the parameters $(p>0.05)$. The statistically significant correlations observed are summarized in table 4.

The changes in clinical parameters within time (baseline, first and last visit) were assessed by the non-parametric Friedman test. Sleep-1 $(\mathrm{p}=0.004)$, total myalgic score $(p=0.003)$, FIQ-total $(p=0.002)$ and HAQ-total $(\mathrm{p}=0.036)$ showed significant differences at follow-up (Table 5). There were no significant differences in pain (VAS, Likert), sleep-2, sleep-3, number of tender points, or BDI at follow-up. The parameters which showed significant differences at

Table 3. Drugs prescribed to the fibromyalgia patients at baseline, the first and last visit

\begin{tabular}{|c|c|c|c|c|c|c|}
\hline & \multicolumn{2}{|c|}{ Baseline } & \multicolumn{2}{|c|}{ First visit } & \multicolumn{2}{|c|}{ Last visit } \\
\hline & $\mathrm{n}$ & $\%$ & $\mathrm{n}$ & $\%$ & $\mathrm{n}$ & $\%$ \\
\hline Amitriptyline & 15 & 5.9 & 23 & 9.1 & 9 & 3.5 \\
\hline Sertraline & 13 & 5.1 & 18 & 7.1 & 13 & 5.1 \\
\hline Paroxetine & 6 & 2.3 & 2 & 0.7 & 3 & 1.5 \\
\hline Escitalopram & 6 & 2.3 & 9 & 3.5 & 4 & 1.5 \\
\hline Venlafaxine & 4 & 1.5 & 10 & 3.9 & 2 & 1.5 \\
\hline Fluoxetine & 3 & 1.1 & 8 & 3.1 & 4 & 1.5 \\
\hline Citalopram & 2 & 0.7 & 6 & 2.3 & 2 & 1.5 \\
\hline
\end{tabular}


Table 4. Correlations of the patient characteristics in fibromyalgia patients ( $\mathrm{r}$ )

\begin{tabular}{|c|c|c|c|c|c|c|c|}
\hline & Pain (VAS) & Pain (Likert) & $\begin{array}{c}\text { Number of } \\
\text { tender points }\end{array}$ & $\begin{array}{c}\text { Total myalgic } \\
\text { score }\end{array}$ & FIQ-total & HAQ-total & BDI-total \\
\hline Pain (Likert) & $0.780^{\star * *}$ & - & $0.156^{*}$ & $0.304^{\star * *}$ & $0.387^{\star * *}$ & $0.337^{\star * *}$ & $0.166^{*}$ \\
\hline Number of tender points & $0.092^{\mathrm{NS}}$ & $0.156^{*}$ & - & $0.665^{\star * *}$ & $0.140^{\star *}$ & $0.347^{\star * *}$ & $0.101^{\mathrm{NS}}$ \\
\hline Total myalgic score & $0.252^{\star * *}$ & $0.304^{\star * *}$ & $0.665^{\star \star *}$ & - & $0.264^{\star \star *}$ & $0.443^{\star * *}$ & $0.091^{\mathrm{NS}}$ \\
\hline Widespread pain & $0.169^{\star *}$ & $0.231^{\star * *}$ & $0.037^{\mathrm{NS}}$ & $0.169^{\star *}$ & $0.139^{*}$ & $0.200^{\star *}$ & $0.037^{\mathrm{NS}}$ \\
\hline Morning stiffness & $0.115^{\mathrm{NS}}$ & $0.167^{\star *}$ & $0.134^{*}$ & $0.208^{\star * *}$ & $0.369^{\star * *}$ & $0.307^{\star * *}$ & $0.129^{\mathrm{NS}}$ \\
\hline Sleep disorder & $0.160^{*}$ & $0.204^{\star * *}$ & $0.068^{\mathrm{NS}}$ & $0.106^{\mathrm{NS}}$ & $0.220^{\star * *}$ & $0.185^{\star *}$ & $0.243^{\star *}$ \\
\hline Dry eye & $0.131^{\star}$ & $0.212^{\star * *}$ & $0.167^{\star *}$ & $0.186^{\star *}$ & $0.180^{\star *}$ & $0.200^{\star *}$ & $0.217^{\star *}$ \\
\hline Dry mouth & $0.070^{\mathrm{NS}}$ & $0.101^{\mathrm{NS}}$ & $0.214^{* * *}$ & $0.139^{*}$ & $0.124^{*}$ & $0.119^{\mathrm{NS}}$ & $0.264^{* * *}$ \\
\hline Female urethral syndrome & $0.160^{*}$ & $0.175^{\star *}$ & $0.099^{\mathrm{NS}}$ & $0.062^{\mathrm{NS}}$ & $0.271^{\star * *}$ & $0.149^{*}$ & $0.109^{\mathrm{NS}}$ \\
\hline Subjective swelling & $0.175^{\star *}$ & $0.170^{\star *}$ & $0.283^{* * *}$ & $0.149^{*}$ & $0.173^{\star \star}$ & $0.170^{\star *}$ & $0.190^{*}$ \\
\hline Paresthesia & $0.101^{\mathrm{NS}}$ & $0.152^{*}$ & $0.160^{*}$ & $0.165^{\star *}$ & $0.198^{\star *}$ & $0.258^{\star * *}$ & $0.231^{\star *}$ \\
\hline Headache & $0.032^{\mathrm{NS}}$ & $0.043^{\mathrm{NS}}$ & $0.134^{*}$ & $0.215^{\star * *}$ & $0.145^{\star}$ & $0.191^{\star *}$ & $0.150^{\mathrm{NS}}$ \\
\hline FIQ-total & $0.387^{\star * *}$ & $0.387^{\star * *}$ & $0.140^{*}$ & $0.264^{\star * *}$ & - & $0.435^{\star * *}$ & $0.263^{* * *}$ \\
\hline HAQ-total & $0.271^{\star * *}$ & $0.337^{\star * *}$ & $0.347^{\star * *}$ & $0.443^{\star * *}$ & $0.435^{\star * *}$ & - & $0.229^{\star *}$ \\
\hline BDI-total & $0.108^{\mathrm{NS}}$ & $0.166^{*}$ & $0.101^{\mathrm{NS}}$ & $0.091^{\mathrm{NS}}$ & $0.263^{* * *}$ & $0.229^{\star *}$ & - \\
\hline
\end{tabular}

VAS: Visual analog scale; FIQ: Fibromyalgia impact questionnaire; HAQ: Health assessment questionnaire; BDI: Beck depression inventory; ${ }^{*}: \mathrm{p}<0.05{ }^{* *}: \mathrm{p}<0.01 ;{ }^{* * *}$ : $\mathrm{p}<0.001$; NS: Not significant.

follow-up (sleep-1, total miyalgic score, FIQ-total and HAQ-total) were again analyzed for any correlation with age, disease duration, BDI total, tender points and initial pain (VAS) scores, but there were no correlations among these parameters $(\mathrm{p}>0.05)$.

Unfortunately, not all patients had complete records of their treatments since there were missing visits or drop-outs. Hence, the analysis done on the effect of drugs could not be generalized and was performed only on a subgroup of patients registered. Between the baseline and the last visit, the FIQ-total, total myalgic score and sleep-1 improved significantly in all patients; the FIQ-total and pain (VAS) improved significantly in patients who had been administered SSRI drugs by the non-parametric Wilcoxon test $(\mathrm{p}<0.05)$, and there was no significant difference between the first and the last visit $(\mathrm{p}>0.05)$. The patients who were treated by amitriptyline showed significant improvement in sleep-1, but no significant difference in clinical parameters was detected for sertraline.

\section{DISCUSSION}

In this study, the demographic and clinical characteristics with functional status of the patients referred to the clinic FOC with chronic widespread pain over the last ten years were analyzed and discussed in many aspects. Most of the FMS patients were female, married, and housewives which is similar to what

Table 5. Change in pain intensity, sleep disorder, tender points, myalgic score, FIQ, HAQ and BDI in different time intervals in fibromyalgia patients

\begin{tabular}{|c|c|c|c|c|c|c|c|}
\hline & \multicolumn{2}{|c|}{ Baseline } & \multirow{2}{*}{\multicolumn{2}{|c|}{$\frac{\text { First visit }}{\text { Median (min.-max.) }}$}} & \multirow{2}{*}{\multicolumn{2}{|c|}{$\frac{\text { Last visit }}{\text { Median (min.-max.) }}$}} & \multirow[t]{2}{*}{$p$} \\
\hline & Media & (min.-max.) & & & & & \\
\hline \multicolumn{8}{|l|}{ Pain intensity } \\
\hline VAS (mm) & 67 & $(0-100)$ & 59.5 & $(0-100)$ & 64.5 & $(3-100)$ & 0.074 \\
\hline Likert (0-4) & 2 & $(0-4)$ & 2 & $(0-4)$ & 2 & $(1-4)$ & 0.748 \\
\hline Sleep-1 (day) & 3 & $(0-7)$ & 2 & $(0-7)$ & 2 & $(0-7)$ & 0.004 \\
\hline Sleep-2 (0-2) & 1 & $(0-2)$ & 1 & $(0-2)$ & 1 & $(0-2)$ & 0.321 \\
\hline Sleep-3 (0-2) & 2 & $(0-2)$ & 2 & $(0-2)$ & 2 & $(0-2)$ & 0.638 \\
\hline Tender points & 16 & $(2-18)$ & 14 & $(0-18)$ & 14 & $(5-18)$ & 0.479 \\
\hline Myalgic score & 23 & $(2-44)$ & 19 & $(0-47)$ & 21 & $(6-42)$ & 0.003 \\
\hline FIQ-total & 5.65 & $(0.74-9.40)$ & 4.93 & $(0.99-7.22)$ & 4.85 & $(2.52-8.52)$ & 0.002 \\
\hline HAQ-total & 0.42 & $(0-1.68)$ & 0.32 & $(0-1.79)$ & 0.42 & $(0-1.79)$ & 0.036 \\
\hline BDI-total & 13 & $(0-41)$ & 12 & $(0-54)$ & 15 & $(0-27)$ & 0.135 \\
\hline
\end{tabular}


has been observed in many clinical studies. ${ }^{[16-18]}$ The female/male ratio was 49:1 whereas it was reported to be between 9:1 and 20:1 in different studies. ${ }^{[19,20]}$ There may be two reasons for the difference in preponderance of females observed in our population. First, fewer men may be suspected to have FMS and referred to a specialized clinic (clinicians' negligence). Second, less men who have FMS symptoms, which are mostly subjective consult a physician (patients' negligence), since men have to be strong and not complain of pain in our patriarchal culture. These are suppositions to be proved by further clinical studies.

The $18 \%$ of the patients referred with chronic widespread pain were not diagnosed with FMS after detailed and FMS-oriented assessment. The disease duration, number of tender points, total myalgic score, HAQ-total, and existence of a set of symptoms such as headache, paresthesia, sleep disorders, morning stiffness, etc. showed significant differences between FMS (+) and FMS (-) patients. A study conducted by Fitzcharles and Boulos, ${ }^{[21]}$ reported a high inaccuracy in FMS diagnosis since only $34 \%$ of the initial diagnoses were found to be correct. Differentiating FMS patients from other patients also having chronic pain by clinical symptoms and signs is necessary in order to determine appropriate treatment strategies, albeit the outcome is not always satisfying. Indeed, Undeland and Malterud, ${ }^{[22]}$ stated that sometimes diagnosis of FMS is hardly helpful for the patients.

Cöster et al. ${ }^{[23]}$ defined FMS as chronic widespread pain with widespread allodynia to pressure. Their main hypothesis was that widespread allodynia distinguishes FMS from chronic widespread pain. They compared different clinical characteristics and functional consequences among two subgroups. One subgroup had chronic widespread pain with widespread allodynia (which is FMS according to the ACR criteria). The other subgroup had chronic widespread pain without widespread allodynia (i.e. $\leq 11$ tender points). They concluded that a high number of tender points in chronic widespread pain was associated more with clinical pain, negative consequences associated with pain, disability, and health-related quality of life. In our analysis, the pain intensity and its impact on sleep disturbance was similar in both groups, but the number of tender points and the total myalgic score were significantly higher in FMS patients. The statistically significant difference between patients with and without FMS in terms of tender points, may confirm the importance of the number of tender points as a predictor for the diagnosis of FMS.
In clinical practice, patients tend to report a complex set of complaints, including fatigue, sleep dysfunction, stiffness, depression, anxiety, poor physical functioning, and cognitive disturbance in addition to pain/tenderness. ${ }^{[4]}$ The five most common clinical symptoms of the FMS patients in our study were fatigue, widespread pain, headache, paresthesia and sleep disorders respectively. However, musculoskeletal pain, fatigue and sleep disorders were reported to be the most common symptoms among FMS patients in another study. ${ }^{[2]}$ Fibromyalgia patients, themselves, identify symptom domains that have the greatest impact on their quality of life as pain, sleep disturbance, fatigue, depression, anxiety, and cognitive impairment. ${ }^{[25]}$

Another study, ${ }^{[26]}$ reports that $22 \%$ of lupus patients were found to meet the criteria for concomitant FMS, experiencing greater disability than patients with lupus alone. In another study, it was found that $12 \%$ of patients with rheumatoid arthritis and 7\% of patients with osteoarthritis fulfilled the FMS criteria. ${ }^{[27]}$ In this study population, a lower rate of concomitant rheumatic diseases than the previous reports was observed. This may be due to the fact that some of the patients with other inflammatory rheumatic diseases such as rheumatoid arthritis were probably referred to the related follow-up outpatient clinics first. Whether or not concomitant fibromyalgia symptoms were taken into consideration is unknown.

This study found that clinical features of FMS patients correlated well with the FIQ, HAQ and BDI. The FIQ correlated with pain intensity, number of tender points, total myalgic score, duration of morning stiffness, existence of widespread pain, sleep disorder, paresthesia, dry eye, dry mouth, headache, female urethral syndrome, subjective swelling and also with HAQ and BDI. There are few studies analyzing the factors that might affect the impact of the disease itself in FMS patients. In those studies, the FIQ correlated with depressed mood ${ }^{[18]}$ and the number of tender points ${ }^{[28]}$ similar to our findings. Since musculoskeletal disorders and related symptoms directly affect patients' functional activities, the relationship between pain and sleep disorder is understandable with FIQ. On the other hand, the correlation between the accompanying symptoms like dry mouth, dry eye and female urethral syndrome and FIQ and BDI are not relevant since they are all dependent variables.

Detecting existing mood disorders is important in the assessment of FMS patients since they have 
higher levels of anxiety and depression than healthy individuals. ${ }^{[16,23,29]}$ The BDI was used to screen depression, and HAQ along with FIQ was used to screen disability in the present study. Tander et al. ${ }^{[16]}$ also observed a similar mean score of BDI in their FMS patients. Gowans et al. ${ }^{[30]}$ recommended using BDI to screen depression in patients with FMS. However, Peleg et al. ${ }^{[31]}$ used the anxiety and depression subscales of Arthritis Impact Measurement Scale for psychological status and the SF-36 for quality of life. In this study, the clinical evaluation parameters were quite similar to ours. FMS patients were assessed by recording the number of tender points, the FIQ, VAS for pain, fatigue, morning stiffness and global wellbeing; and headache frequency, paresthesia, sleep disturbance, subjective joint swelling, and irritable bowel syndrome. Similarly, they detected a high level of pain and fatigue, a high frequency of paresthesia, headache and irritable bowel syndrome. However, the mean FIQ score of our study population was higher than those reported by Peleg.

The main limitation of our study is the lack of satisfactory statistical data regarding the effects of different treatment modalities on outcome since many treatment modalities were administered in a step-up policy when required. Thus, the number of patients in each treatment modality group alone was insufficient to perform a proper statistical analysis. Limited data demonstrated a significant improvement in sleep disorder only with amytriptiline. In a systematic review, amitriptyline was also shown to be an effective drug in diminishing pain, fatigue, and depression while improving sleep and quality of life. ${ }^{[32]}$ Nöller and $S_{\text {prot }}{ }^{[33]}$ stated no improvement in symptoms of their FMS patients in the two-year follow-up regardless of the type of therapy they had received. However, almost half the patients had clinically meaningful improvement in overall FMS status in a 40 month longitudinal study. ${ }^{[34]}$ Outcome analysis of our patient group showed no improvement in some parameters. Although there were improvements regarding functionality by FIQ, no significant differences were detected in the level of pain, sleep and BDI scores among the FS (+) patients at followup. In fact, one of the goals in the treatment of FMS is to improve functionality along with attenuating pain. Most probably, an in-depth analysis of patients' characteristics in conjunction with the application of the most appropriate treatments would result in better outcomes. A systematic analysis showed that despite major limitations in treatment studies, current evidence suggests the efficacy of low dose tricyclic antidepressants, cardiovascular exercise, cognitive behavioral therapy, and patient education. ${ }^{[35]}$ Goldenberg et al. ${ }^{[35]}$ also stated that current evidence indicates a stepwise program emphasizing education, certain medications, exercise, cognitive therapy, or all four should be recommended.

There is a lack of information on the long-term outcome of patients with FMS. In one study there were promising results with education and exercise after 6-8 years follow-up ${ }^{[36]}$ while in another study only $20 \%$ of the patients reported improvements after five years. ${ }^{[37]}$ In both studies, the number of patients was limited (33 and 56 respectively). Hence, our study with a large number of patients seen in a specialized outpatient clinic and their long-term follow-up might support our findings about FMS outcome. On the other hand, a meta-analysis showed that treating FMS in specialized care offers no clear advantages over primary care. The authors suggested the heterogeneity of the specialized care studies, their low quality and short duration were limitations. ${ }^{[38]}$

In conclusion, our ten year experience with the long-term follow-up of FMS patients in a specialized outpatient clinic showed us that FMS is a multifaceted condition which is not easy to cope with. To distinguish patients with FMS from patients with other widespread pain conditions is crucial, and clinical diagnostic decisions seem to be supported by the ACR classification criteria since the significant difference between these groups in our cohort were in the tender point count and the existence of accompanying symptoms in FMS. In our patient population the long-term outcome is not promising although there were some improvements in sleep and functionality. In our opinion, it is essential to evaluate every patient with FMS individually according to predominant clinical feature in order to apply the best treatment since it is a disorder with various clinical signs and symptoms. Subgrouping the patients may be beneficial for treatment and long-term follow-up is necessary in order to ensure outcomes.

\section{Declaration of conflicting interests}

The authors declared no conflicts of interest with respect to the authorship and/or publication of this article.

\section{Funding}

The authors received no financial support for the research and/or authorship of this article. 


\section{REFERENCES}

1. Mas AJ, Carmona L, Valverde M, Ribas B; EPISER Study Group. Prevalence and impact of fibromyalgia on function and quality of life in individuals from the general population: results from a nationwide study in Spain. Clin Exp Rheumatol 2008;26:519-26.

2. Wolfe F, Smythe HA, Yunus MB, Bennett RM, Bombardier C, Goldenberg DL, et al. The American College of Rheumatology 1990 Criteria for the Classification of Fibromyalgia. Report of the Multicenter Criteria Committee. Arthritis Rheum 1990;33:160-72.

3. Wolfe F, Anderson J, Harkness D, Bennett RM, Caro XJ, Goldenberg DL, et al. A prospective, longitudinal, multicenter study of service utilization and costs in fibromyalgia. Arthritis Rheum 1997;40:1560-70.

4. Mease P. Fibromyalgia syndrome: review of clinical presentation, pathogenesis, outcome measures, and treatment. J Rheumatol Suppl 2005;75:6-21.

5. Yunus MB. Central sensitivity syndromes: a new paradigm and group nosology for fibromyalgia and overlapping conditions, and the related issue of disease versus illness. Semin Arthritis Rheum 2008;37:339-52.

6. Schweinhardt P, Sauro KM, Bushnell MC. Fibromyalgia: a disorder of the brain? Neuroscientist 2008;14:415-21.

7. Giesecke T, Williams DA, Harris RE, Cupps TR, Tian X, Tian TX, et al. Subgrouping of fibromyalgia patients on the basis of pressure-pain thresholds and psychological factors. Arthritis Rheum 2003;48:2916-22.

8. Turk DC, Okifuji A, Sinclair JD, Starz TW. Pain, disability, and physical functioning in subgroups of patients with fibromyalgia. J Rheumatol 1996;23:1255-62.

9. Müller W, Schneider EM, Stratz T. The classification of fibromyalgia syndrome. Rheumatol Int 2007;27:1005-10.

10. Burckhardt CS, Clark SR, Bennett RM. The fibromyalgia impact questionnaire: development and validation. J Rheumatol 1991;18:728-33.

11. Sarmer S, Ergin S, Yavuzer G. The validity and reliability of the Turkish version of the Fibromyalgia Impact Questionnaire. Rheumatol Int 2000;20:9-12.

12. Fries JF, Spitz P, Kraines RG, Holman HR. Measurement of patient outcome in arthritis. Arthritis Rheum 1980;23:137-45.

13. Küçükdeveci AA, Sahin H, Ataman S, Griffiths B, Tennant A. Issues in cross-cultural validity: example from the adaptation, reliability, and validity testing of a Turkish version of the Stanford Health Assessment Questionnaire. Arthritis Rheum 2004;51:14-9.

14. Beck AT, Ward CH, Mendelson M, Mock J, Erbaugh J. An inventory for measuring depression. Arch Gen Psychiatry 1961;4:561-71.

15. Hisli N. The validity and reliability of Beck Depression Inventory for university students. Turkish J Psychol 1989; 6:3-13.

16. Tander B, Cengiz K, Alayli G, Ilhanli I, Canbaz S, Canturk F. A comparative evaluation of health related quality of life and depression in patients with fibromyalgia syndrome and rheumatoid arthritis. Rheumatol Int 2008;28:859-65.
17. Alamo MM, Moral RR, Pérula de Torres LA. Evaluation of a patient-centred approach in generalized musculoskeletal chronic pain/fibromyalgia patients in primary care. Patient Educ Couns 2002;48:23-31.

18. Ubago Linares Mdel C, Ruiz-Pérez I, Bermejo Pérez MJ, Olry de Labry-Lima A, Hernández-Torres E, PlazaolaCastaño J. Analysis of the impact of fibromyalgia on quality of life: associated factors. Clin Rheumatol 2008;27:613-9.

19. Burckhardt CS, Jones KD, Clark SR. Soft tissue problems associated with rheumatic disease. Lippincotts Prim Care Pract 1998;2:20-9.

20. Schneider MJ. Tender points/fibromyalgia vs. trigger points/myofascial pain syndrome: a need for clarity in terminology and differential diagnosis. J Manipulative Physiol Ther 1995;18:398-406.

21. Fitzcharles MA, Boulos P. Inaccuracy in the diagnosis of fibromyalgia syndrome: analysis of referrals. Rheumatology (Oxford) 2003;42:263-7.

22. Undeland $M$, Malterud K. The fibromyalgia diagnosis: hardly helpful for the patients? A qualitative focus group study. Scand J Prim Health Care 2007;25:250-5.

23. Cöster L, Kendall S, Gerdle B, Henriksson C, Henriksson KG, Bengtsson A. Chronic widespread musculoskeletal pain - a comparison of those who meet criteria for fibromyalgia and those who do not. Eur J Pain 2008;12:600-10.

24. White KP, Speechley M, Harth M, Ostbye T. The London Fibromyalgia Epidemiology Study: comparing the demographic and clinical characteristics in 100 random community cases of fibromyalgia versus controls. J Rheumatol 1999;26:1577-85.

25. Arnold LM, Crofford LJ, Mease PJ, Burgess SM, Palmer SC, Abetz L, et al. Patient perspectives on the impact of fibromyalgia. Patient Educ Couns 2008;73:114-20.

26. Martínez-Lavín M. Overlap of fibromyalgia with other medical conditions. Curr Pain Headache Rep 2001; 5:347-50.

27. Pérez-Stable EJ, Miranda J, Muñoz RF, Ying YW. Depression in medical outpatients. Underrecognition and misdiagnosis. Arch Intern Med 1990;150:1083-8.

28. Fallon J, Bujak DI, Guardino S, Weinstein A. The Fibromyalgia Impact Questionnaire: a useful tool in evaluating patients with post-Lyme disease syndrome. Arthritis Care Res 1999;12:42-7.

29. Chakrabarty S, Zoorob R. Fibromyalgia. Am Fam Physician 2007;76:247-54.

30. Gowans SE, DeHueck A, Abbey SE. Measuring exerciseinduced mood changes in fibromyalgia: a comparison of several measures. Arthritis Rheum 2002;47:603-9.

31. Peleg R, Ablin JN, Peleg A, Neumann L, Rabia RA, Buskila D. Characteristics of fibromyalgia in Muslim Bedouin women in a primary care clinic. Semin Arthritis Rheum 2008;37:398-402.

32. Uçeyler N, Häuser W, Sommer C. A systematic review on the effectiveness of treatment with antidepressants in fibromyalgia syndrome. Arthritis Rheum 2008; 59:1279-98 
33. Nöller V, Sprott H. Prospective epidemiological observations on the course of the disease in fibromyalgia patients. J Negat Results Biomed 2003;2:4.

34. Fitzcharles MA, Costa DD, Pöyhiä R. A study of standard care in fibromyalgia syndrome: a favorable outcome. J Rheumatol 2003;30:154-9.

35. Goldenberg DL, Burckhardt C, Crofford L. Management of fibromyalgia syndrome. JAMA 2004; 292:2388-95.
36. Mengshoel AM, Haugen M. Health status in fibromyalgia-a followup study. J Rheumatol 2001;28:2085-9.

37. Henriksson CM. Longterm effects of fibromyalgia on everyday life. A study of 56 patients. Scand J Rheumatol 1994;23:36-41.

38. Garcia-Campayo J, Magdalena J, Magallón R, FernándezGarcía E, Salas M, Andrés E. A meta-analysis of the efficacy of fibromyalgia treatment according to level of care. Arthritis Res Ther 2008;10:R81. 